\title{
Ambulante forensisch-psychiatrische behandelingen op de AFPN
}

\author{
H. Wubs ${ }^{*}$ \\ G.H. Wijnen ${ }^{* * *}$
}

\section{Inleiding}

De forensische psychiatrie in Nederland maakt een snelle ontwikkeling door. Tot het eind van de jaren ' 80 werd de forensische psychiatrie bijna uitsluitend beoefend in de TBS-klinieken bij de tenuitvoerlegging van de TBSmaatregel met dwangverpleging. In de jaren ' 90 werden de klinische behandelmogelijkheden aanzienlijk uitgebreid met de opening c.q. uitbreiding van een drietal forensisch psychiatrische klinieken (FPK's) en verscheidene forensische psychiatrische afdelingen (FPA's). Het werd mogelijk om ook forensisch-psychiatrische patiënten te behandelen in het kader van andere juridische maatregelen. De ontwikkeling van de ambulante forensische psychiatrie was een volgende voorspelbare en logische voortzetting. Enerzijds omdat de ambulante forensische psychiatrie een nazorgvoorziening biedt voor patiënten na een klinische behandeling of detentie. Anderzijds omdat het een antwoord biedt op de groeiende maatschappelijke vraag naar een meer gespecialiseerde ambulante psychiatrische zorg voor psychiatrische patiënten, die door hun gedrag in aanraking zijn gekomen met justitie en waarbij een opname niet noodzakelijk of mogelijk is.

In 1998 is de forensische polikliniek vanuit de FPK in Assen gestart. Op de Ambulante Forensische Psychiatrie Noord-Nederland (AFPN) zijn er in de afgelopen jaren behandelprogramma's ontwikkeld voor veelal moeilijke en ingewikkelde problematiek.

In deze bijdrage gaan we allereerst in op de aanmeldingsroute en het behandelaanbod van de AFPN in het algemeen en daarna op de diagnostiek en de behandeling van patiënten met seksuele stoornissen in het bijzonder.

* Harry Wubs is GZ-psycholoog en werkzaam op de AFPN.

** Gery Wijnen is psychotherapeut en werkzaam als behandelcoördinator op de AFPN te Groningen. 


\section{Ambulante Forensische Psychiatrie Noord-Nederland}

De Ambulante Forensische Psychiatrie Noord-Nederland (AFPN) is een GGZ-voorziening. De AFPN is een samenwerkingsverband van GGZ Drenthe, GGZ Friesland en GGZ Groningen en de Dr. S. van Mesdagkliniek. Het is een forensisch psychiatrisch centrum dat zich richt op de ambulante behandeling van mensen die psychiatrische en/of psychische problemen hebben en met Justitie in aanraking zijn of dreigen te komen. De AFPN biedt haar diensten aan op drie locaties: in Assen, Groningen en Leeuwarden. We vormen een onderdeel van het Forensisch Psychiatrisch Circuit Hofressort Leeuwarden (FPC-L). De AFPN werkt nauw samen met andere GGZinstellingen in de regio en met aan Justitie gelieerde instellingen, met name de reclassering.

Forensische psychiatrie: werken in de marge tussen GGZ en Justitie.

De forensische psychiatrie bevindt zich op de grens van twee domeinen: strafrecht en zorg. Ze belandt daarmee in een ingewikkeld en dynamisch krachtenveld tussen twee ministeries, VWS en Justitie, met verschillende culturen en besturingsmodellen. Dit betekent dat er een dialoog zal moeten zijn over de rol en positie van de verschillende partijen op basis van hun verantwoordelijkheden op verschillend gebied. Bij de forensischpsychiatrische behandeling gaat het om het behandelen van 'gestoord' gedrag en niet om het straffen van 'storend' gedrag. Op de AFPN worden regelmatig 'lastige lieden' aangemeld, met wie niemand wat kan en die al jaren zorg mijden. Bij de reguliere GGZ-instellingen staan ze bekend als 'draaideurcliënten'. Is de AFPN daarvoor aangewezen? De AFPN is laagdrempelig en meer gespecialiseerd in de benadering van ernstig gestoorde patiënten. De behandelaars van de AFPN moeten zich echter te allen tijde afvragen: kunnen wij deze cliënt/patiënt begeleiden c.q. behandelen? De AFPN is er niet voor het beteugelen van onrust en overlast in de maatschappij.

\section{Uitgangspunten}

De uitgangspunten van de AFPN zijn als van de GGZ. Leidregels zijn onder andere: zorg op maat, de Wet op de Geneeskundige Behandelovereenkomst (WGBO), het privacyreglement van de Wet op de Bescherming van Persoonsgegevens (WBP) en de klachtenregeling van de BOPZ. De betaling van de behandelingen verloopt via de ziektekostenverzekering. Er wordt geen eigen bijdrage van de patiënt gevraagd. Er wordt op de AFPN gewerkt 
volgens het medisch model. Dit bestaat uit intakegesprekken, diagnostiekbespreking en behandelingadvies. Gaat de patiënt akkoord met het behandelaanbod dan wordt er een behandelplan opgesteld. Dit wordt ondertekend door patiënt en behandelaar. Ook wordt er een samenwerkingsovereenkomst getekend waarin afspraken staan over veiligheid, delictgedrag, middelengebruik en privacy.

De psychopathologie varieert. Veelvoorkomende stoornissen zijn onder meer persoonlijkheidsstoornissen, impulsstoornissen en agressieregulatieproblematiek en seksuele stoornissen. Voorts kunnen afhankelijkheid van middelen, depressiviteit, dissociaties, angst en psychosen een belangrijke rol spelen. De aanmelding van patiënt gebeurt vrijwillig, bijvoorbeeld door huisarts of GGZ-instelling, maar kan ook plaatsvinden in het kader van een juridische maatregel. Ook in deze gevallen zal de patiënt moeten instemmen met verwijzing c.q. behandeling. De delicten variëren van diefstal, inbraak en mishandeling tot levensdelicten en van minder ernstige tot ernstige seksuele delicten. Aanmelding van TBS'ers voor poliklinische behandeling komt voor als er nazorg geïndiceerd is of als onderdeel van een voorwaardelijke beëindiging van de TBS. Er heeft dan al een langdurige behandeling in een TBS-kliniek plaatsgevonden.

\section{Behandelaanbod}

Het behandelaanbod bestaat uit poliklinische behandeling (individuele en/of groepsbehandeling), deeltijdbehandeling (dagbehandeling), forensisch psychiatrische thuiszorg (FPTZ) en het project 'Daderhulp Thuisgeweld'. Daarnaast is er een pilot, geheten: 'Behandelen in detentie'.

De poliklinische groepsbehandelingen ( $1 \frac{1}{2}$ uur per week) zijn divers. Zo bestaan er een trainingsgroep voor patiënten met een seksuele stoornis, een delictscenariogroep voor patiënten met exhibitionisme, een delictscenarioen delictverwerkingsgroep, communicatietraining, sociale vaardigheidstrainingen, een terugvalpreventiegroep voor patiënten met seksuele problematiek en exhibitionisme en hands off-delicten, een partnergroep voor partners van forensische patiënten, een ondersteuningsgroep voor FPTZ-patiënten en een groep voor plegers van relationeel geweld.

De deeltijdbehandelingen bestaan uit bijeenkomsten van een of meerdere dagen per week gedurende een periode van 3, 6 of 12 maanden. Voorbeelden zijn: eendaagse deeltijdbehandeling voor patiënten met agressieregulatie/ 
impulsproblematiek, een trainingsgroep geheten 'Held zonder geweld', een eendaagse deeltijdbehandeling voor exhibitionisten en hands off-delicten, een eendaagse deeltijdbehandeling voor zwakbegaafden met agressieregulatie-problematiek, een eendaagse deeltijdbehandeling voor zwakbegaafden met seksueel grensoverschrijdend gedrag, een vierdaagse deeltijdbehandeling voor patiënten met ernstig seksuele problematiek (incest/ontucht minderjarigen) en de 'Vaardigheidstraining Emotie Regulatie Stoornis' (VERS).

\section{Ambulante behandeling van seksuele delinquenten}

Naast de reguliere psychodiagnostiek biedt het 4-faktoren model van D. Finkelhor ${ }^{1}$ belangrijke aanknopingspunten voor behandeling van patiënten met seksuele stoornissen.

Finkelhor onderscheidt vier complexen van factoren. Ten eerste de motieven om te misbruiken (gedachten, fantasieën). De vraag die in dit verband moet worden gesteld is, wat de dader 'drijft' tot het plegen van het delict. Ten tweede zijn er de factoren die te maken hebben met het overwinnen van interne remmingen (des-inhibitie). Gewetenloze psychopaten behandelen we nauwelijks in de ambulante forensisch psychiatrie en dus moet de dader zijn geweten op de een of andere manier hebben omzeild. Het derde aanknopingspunt is het overwinnen van externe remmingen (manipuleren van de omgeving) en het vierde aanknopingspunt betreft de factoren die betrekking hebben op het overwinnen van de weerstand van het slachtoffer. Het nauwkeurig analyseren van deze vier complexen van factoren biedt belangrijke gegevens over de psychologische mechanismen van de dader (het typerende voorbereidingsgedrag van de dader) en biedt aangrijpingspunten voor beïnvloeding.

Het is voorts van belang om het voorbereidingsproces te analyseren. Op basis van onderzoek bij slachtoffers van seksueel kindermisbruik onderscheiden we drie fasen in het voorbereidingsproces. Het begint ermee dat de dader de relatie seksualiseert. Vervolgens wordt het seksuele contact min of meer gerechtvaardigd of het seksuele wordt ontkend. Tenslotte wordt de 'medewerking' van het kind bewerkstelligd. De bestanddelen in deze planning zijn dat eerst het vertrouwen wordt gewonnen; het kind wordt bevoorrecht. Het kind wordt vervolgens geïsoleerd en gevraagd mee te werken aan

1 D. Finkelhor, Child Sexual Abuse, 1984. 
geheimhouding. Het kind wordt hierdoor medeverantwoordelijk gemaakt. Zo worden stapsgewijs de grenzen verlegd.

\section{Dadertypologie}

In de theorie zijn zeer veel dadertypologieën gemaakt die niet zo bruikbaar zijn in de praktijk van de hulpverlening. Om dicht bij huis te blijven noemen wij een paar onderverdelingen van Nederlandse onderzoekers/auteurs. Bij plegers van seksueel kindermisbruik maakt J. Frenken een simpele verdeling in drie hoofdcategorieën. Dit zijn de pedofiele pleger (kind met de kinderen), de situationele pleger (volwassene met 'volwassenen') en de antisociale pleger (volwassene met kinderen). Op de AFPN zien we vooral de eerste en de tweede categorie, dus de pedofiele en situationele plegers. Op basis van de typologie van D.J.van Beek ${ }^{2}$ worden ook drie categorieën daders onderscheiden: de antisociale pleger, de seksualiserende pleger en de wraakzuchtige pleger.Van deze verdeling zien we op de AFPN vooral de laatste twee categorieën, de seksualiserende en de wraakzuchtige pleger. De antisociale pleger (volwassene met het kind) komt dus het minste voor. Dit is te verklaren door het feit dat dit soort daders in het algemeen intramuraal worden behandeld.

\section{Methodiek/behandeluitgangspunten}

Behandeling is voor de patiënt meestal een pijnlijk en vaak beschamend proces waarvoor hij niet te gemakkelijk op de loop moet kunnen gaan. Omdat er dus meestal sprake is van een lage behandelingsmotivatie is het bij de behandeling van seksuele delinquenten van groot belang om te kunnen werken binnen een min of meer verplichtend juridisch kader, de zogenaamde 'stok achter de deur'. In de behandeling wordt gewerkt volgens het terugvalpreventie-model. Het centrale behandeldoel is altijd het voorkomen van nieuwe delicten of nieuw delictgedrag. Naast het bewerken van de onderliggende psychoseksuele problematiek, wordt er vooral gestreefd naar het aanleren van meer verantwoordelijkheid voor het eigen gedrag, inclusief het delictgedrag. Hierbij zijn het maken van delictanalyse en delictscenario belangrijke onderdelen. Er wordt in de behandeling onderscheiden tussen de fase van zorg en externe controle (care), de fase van training van zelfcontrole (control) en de derde fase, die van behandeling (care). In veel gevallen zal de patiënt niet te genezen zijn van bijvoorbeeld zijn pedofiele geaardheid,

2 D. van Beek, De delictscenarioprocedure bij seksueel agressieve delinquenten, 1999. 
maar kan hij wel controle aanleren over zijn gedrag. Ook dit werkt preventief.

\section{Slot}

De ambulante forensisch-psychiatrische behandeling is betrekkelijk nieuw en nog volop in ontwikkeling. Metingen rond effecten van toegepaste behandelvormen moeten nog plaatsvinden. Wel kan worden vastgesteld dat de vraag naar ambulante behandeling groot is en de AFPN dus in een behoefte voorziet. 